\title{
鉄道車両一軸操舵台車の舵行動周波数に基づく走行安定性設計*
}

\author{
道辻洋 平*1, 須田義 大*2, 岩佐 崇 史*3
}

\section{Design Method of Running Stability Based on Hunting Frequency for Single-Axle Steering Bogie}

\author{
Yohei MICHITSUJI, Yoshihiro SUDA*4 and Takashi IWASA \\ ${ }^{* 4}$ Center for Collaborative Research, The University of Tokyo, \\ 4-6-1 Komaba Meguro-ku, Tokyo, 153-8904 Japan
}

\begin{abstract}
Compatibility between high speed running stability and good curving performance of railway vehicles has long been considered. In the design of vehicle parameters, the axle supporting stiffness is quite important for solving the trade-off. On the contrary, the proposed bogie with steering yaw damper enables the vehicle to realize ideal curving performance on tight curved track while achieving high speed running stability. In order to verify the performance of the newly developed steering truck, the scaled model experimental platform with $1 / 10$ model vehicle is orignnally made. In this paper, the theory of steering bogie to secure high speed running stability is explained. The design procedure is based on the hunting frequency analysis of wheelset considered as a system to be stabilized. Experimental results for the scale model vehicle with two single-axle bogies show good performance for high speed running stability.
\end{abstract}

Key Words: Railway, Damper, Vibration Control Device, Stability Analysis, Steering Bogie

\section{1.}

近年, 新たな鉄道車両台車として，一軸台車が 注目されている(1). 従来の二軸台車と比較した一軸 台車車両の利点は, 低床化, 車体幅拡大, 部品点数 の減少などである. また, 緩和曲線における輪重変 動低減効果など, 急曲線通過性能においても二軸台 車を凌ぐ性能を有する(2). 一方, 一軸台車の課題と なるのが高速走行時の蛇行動安定性である( ${ }^{(3)}$. 実際 に欧州の実用化例をみても，LRT など比較的低速な 車両への応用が主である. このことから, 曲線通過 性能の優位性を確保しつつ, 安定走行可能な速度領 域を拡大できれば, 次世代鉄道車両のグランドデザ インに大きな可能性を与えうる台車と期待できる.

一軸台車において, 高速走行安定性之急曲線旋回 性能の両立に支配的なパラメータは, 枕ばねと軸ば ねの剛性值である( ${ }^{(4)}$.このことは二軸台車の軸箱支 持剛性による蛇行動安定性と曲線通過性の関係と同 様であり,これら剛性の大きさは両性能のトレード

* 原稿受付 2003 年 7 月 16 日.

\footnotetext{
*1 正員, 東京大学大学院工学系研究科(113-8656 東京都文 京区本郷 7-3-1).

*2 正員, 東京大学国際・産学共同研究センター(E 153-8904 東京都目黑区駒場 4-6-1).

*3 正員, 東京大学生産技術研究所.

E-mail : suda@ iis.u-tokyo.ac.jp
}

オフとして決定される(ึ)，一軸台車においては，こ のトレードオフを緩和するために, 台車枠率引リン クを用いた前後非対称化が考えられている(.

本報における提案一軸操舵台車は, 従来の枕ば ね前後支持剛性を高粘性ダンパのみの支持に置き換 えることで, 前後軸ばねとの直列支持構造を有する. これにより周波数可変の前後支持機構となり, 剛支 持台車の高速走行安定性を有しつつ, 前後剛性を零 とした理想的な定常曲線通過を実現する自己操蛇台 車を実現できる(゙。ここでは, 高速走行安定性を十 分に確保するための, 輪軸蛇行動周波数を考慮した 機構パラメー夕設計手法を提案する. また, 提案理 論の有効性を検証するために, 開発した $1 / 10$ スケ 一ルモテル車両の走行安定性を固有値解析によって 実施する. さらに，この模型車両を用いた詳細な走 行実験により, 提案台車の走行安定性向上効果を検 証したので, その内容について報告する.

\section{纪 号}

本報の理論解析で用いる記号の意味を以下に示す.
$m_{w}:$ 輪軸質量
$I_{w}:$ 輪軸慣性モーメント
$v:$ 走行速度 
$\kappa_{11}:$ 縦クリープ係数

$\kappa_{22}:$ 横クリープ係数

$b_{0}:$ 車輪間距離の半分

$r_{0}:$ 車輪半径

$\gamma:$ 踏面勾配

$a:$ 輪軸·車体中心間距離

$b_{1}:$ 輪軸前後支持機構の左右位置

$b_{2}$ : 台車枠前後支持機構の左右位置

$\alpha$ : 支持機構オフセット比（ $\left.\alpha=b_{2} / b_{1}\right)$

$k_{w x}$ : 前後支持ばねのばね定数

$k_{\varphi}:$ 軸箱ヨーインク風性 $\left(k_{\varphi}=b_{1}^{2} k_{w x}\right)$

\section{2. 提案一軸台車の走行安定性設計}

$2 \cdot 1$ 提案台車の概要 提案する操舵台車の車 両構造の概観を図 1 に示す. 図示されるように前·後 軸がそれぞれ台車枠で支持されている一軸台車を二つ 有する車両である. 台車枠·車体間は相対左右変位に 対してばね，前後方向にはダンパで支持されており， 輪軸ヨ一運動に対し, 台車枠を介してダンパが作用す る構造となっている. ここではダンパ部分を特にステ アリング・ヨーダンパ（以下 SYD）とよぶ，提案す る台車構造により, 高速走行時の蛇行動周波数に対し, SYD か焵に作用し台車枠.車体間ヨ一を固定する.こ れにより，輪軸は軸ばねで岡支持され，高い蛇行動臨 界速度を得ることが可能となる. 一方, 定常曲線旋回 時においては, 定常的な前後クリープ力を受けること でSYDが変位し, ステアリング・モ一メントが零に収 束する位置まで自動調整的に操舵する機能をもつ.こ のモ一メントが零となる位置は, いわゆる純粋転がり 線であり, 踏面クリープを最小化した理想的な曲線旋 回運動を実現する.

$2 \cdot 2$ 輪軸の伝遧阙数表現 簡略化モデルを 用いて，提案台車の支持パラメー夕設計手法を導 出する. 解析モデルは図 2 に示されるように, 軌道 と併走しながら，左右を固定された仮想的な車体，前 後支持機構, 輪軸からなる系を考える. このとき車体 は移動座標系に対して自由度を持たず，輪軸は移動座 標系に取り付けた前後支持機構からの拘束を受けるこ ととなる. また，台車枠は中間質量の役割をもつが, 支持機構の岡性パラメー夕に比して值が小さいのでそ の存在を無視する．まず，円錐踏面を有する輪軸単体 の簡略化運動方程式は, 左右変位を $y$, アタック角 を $\varphi$, 前後支持機構によって輪軸に発生するトルク $\tau$ を用いて以下となる.

$$
\begin{gathered}
{\left[\begin{array}{cc}
m_{w} & 0 \\
0 & I_{w}
\end{array}\right]\left[\begin{array}{l}
\ddot{y} \\
\ddot{\varphi}
\end{array}\right]+\frac{1}{v}\left[\begin{array}{cc}
2 \kappa_{22} & 0 \\
0 & 2 \kappa_{11} b_{0}^{2}
\end{array}\right]\left[\begin{array}{l}
\dot{y} \\
\dot{\varphi}
\end{array}\right]} \\
+\left[\begin{array}{cc}
0 & -2 \kappa_{22} \\
\frac{2 \kappa_{11} b_{0} \gamma}{r_{0}} & 0
\end{array}\right]\left[\begin{array}{l}
y \\
\varphi
\end{array}\right]=\left[\begin{array}{l}
0 \\
1
\end{array}\right] \tau
\end{gathered}
$$

このとき，システムの入出力関係を伝達関数によっ て示すと以下となる.

$$
\left[\begin{array}{l}
y \\
\varphi
\end{array}\right]=\left[\begin{array}{l}
G_{y}(s) \\
G_{\varphi}(s)
\end{array}\right] \tau
$$

ここで

$$
\begin{aligned}
N_{1}(s)=2 \kappa_{22}, \quad N_{2}(s)=m_{w} s^{2}+\frac{2 \kappa_{22}}{v} s \\
D(s)=m_{w} I_{w} s^{4}+\frac{2 I_{w} K_{22}+2 m_{w} K_{11} b_{0}^{2}}{v} s^{3} \\
+\frac{4 \kappa_{11} \kappa_{22} b_{0}^{2}}{v^{2}} s^{2}+\frac{4 \kappa_{11} \kappa_{22} b_{0} \gamma}{r_{0}}
\end{aligned}
$$

を用いて

$$
\begin{aligned}
G_{y}(s) & =\frac{N_{1}(s)}{D(s)} \\
G_{\varphi}(s) & =\frac{N_{2}(s)}{D(s)}
\end{aligned}
$$

である.このとき, 分母多項式の性質から輪軸単体 は2つの複素共役な不安定極を有する系となる.

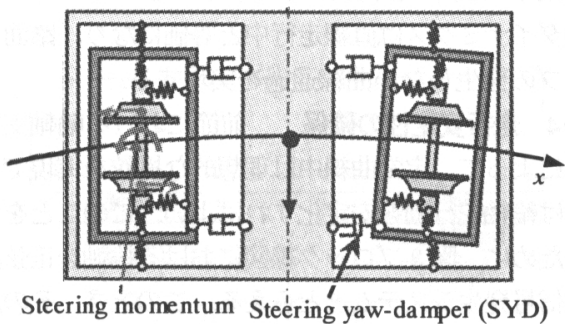

Fig. 1 Proposed bogie mechanism

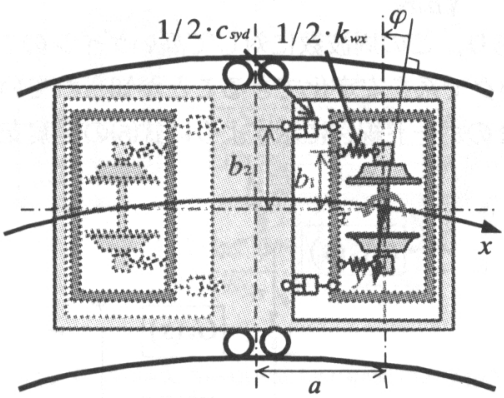

Fig. 2 Analytic model of wheel-axle with absolutely constrained vehicle body 
$2 \cdot 3$ ステアリング・ヨーダンパの好果次 に, 前後支持機構による作用力を考虑した場合を 考える. 図 2 に示されるように, SYD と前後軸ば ねの直列機構について, 入力を車体·輪軸間相対ヨ一 角であるステア角 $\varphi_{s}$, 出力を発生トルク $\tau$ とした, 回転ばわの岡性に対応する伝達関数表現は以下となる.

$$
K_{\varphi}(s)=k_{\varphi} \frac{T s}{T s+1}, \quad T=\alpha c_{\text {s⿱d }} / k_{\text {wx }}
$$

この周波数特性を有するばねは,

$$
K_{\varphi}(0)=0, \quad K_{\varphi}(\infty)=k_{\varphi}
$$

という二つの性質を有する. 輪軸に作用するトルクを, 曲線通過を含めて考えると

$$
\tau=-K_{\varphi}(s) \cdot \varphi s
$$

となる. 輪軸ステア角はアタック角を用いて

$$
\varphi_{s}=\varphi-a \rho
$$

である. ここで $\rho$ は輪軸走行位置の軌道曲率である. この系で出力を輪軸アタック角, 入力を軌道曲率とし た SISO システムを, ブロック線図で記述すると図 3 のようになる. このブロック線図をみると, 支持剛 性は輪軸アタック角に対してフィードバック補僙器と なり, 不安定な制御対象を安定化する役割をもつ. ま た, 軌道の曲率がヨ一岡性分, 拡大されて入力端に入 り込んでいる. 提案支持機構では，DC ゲインが䨐と なる伝達関数特性により定常円旋回する輪軸について は，図中の曲率入力 $\tau_{\mathrm{c}}$ が零に収束する.これにより， 輪軸ダイナミクスは直線走行中と等価になり, 踏面ク リープの発生しない曲線通過を実現する.

2.4 走行安定性の的保 前節における輪軸支持 機構によって, 定常曲線中は理想的な操宛を実現でき, あとは輪軸蛇行動を安定化すればよい．このことを考 えるために，図3ブロック線図における輪軸を正弦波 状の信号発生システムととらえる. このとき, その周 波数は蛇行動周波数

$$
\omega_{v}=v \sqrt{\frac{\gamma}{b_{0} r_{0}}}
$$

であり, この周波数に対して高いゲインのフィー ドバックで系を安定化できることが知られている。

図4のボード線図に示すように式(5)の提案支持機

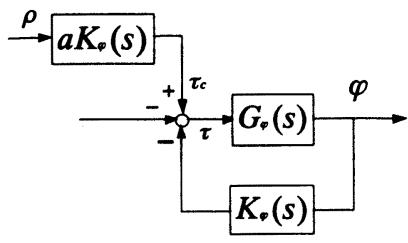

Fig 3 Block diagram of wheel set system with suspension
構は, 設計パラメータ $T$ に依存したゲインの飽和特 性を有する. 飽和したゲインの值はばね定数に等しく 位相遅れも無い.このことから, ある走行速度におけ る蛇行動周波数 $\omega_{v}$ に対して, 機構のパラメータを

$$
\frac{2}{T} \leq \omega_{v}
$$

と選ぶことで, 想定する走行速度以上で剛支持台車 の走行安定性を確保できる. 想定最高速度を $v_{\text {max }}$ と して, 上式をパラメータで具体的に表すと

$$
\frac{2 k_{\text {wx }}}{\alpha c_{s d d}} \leq v_{\max } \sqrt{\frac{\gamma}{b_{0} r_{0}}}
$$

となる. ばね定数 $k_{w x}$ とダンパ減衰俰数 $c_{5 \text { sd }}$ のパラ メー夕空間で表示した図 5 を用いて, 車両の設計手 順を示すと以下のようになる.

まず，曲線通過性のみを考虑した輪軸踏面勾配 $\gamma$ を設計し, 想定最高速度 $v_{\max }$ における蛇行動周波数 $\omega_{\max }$ を算出する. 次に, SYD の動作を固定し, 枕 ばね前後支持剛性を無限大とした場合を考え, $v_{\max }$ でも安定となる, 軸ばね前後剛性の最小值 $\boldsymbol{k}_{\text {min }}$ を車 両モデルの固有値解析で計算する. 最後に, 計算し た軸ばね前後剛性の值から, SYD の最小減衰倸数 $c_{\text {min }}$ を式(10)に基づいて決定する. 実際の值は余裕 を持ってそれより大きな值を設定する.

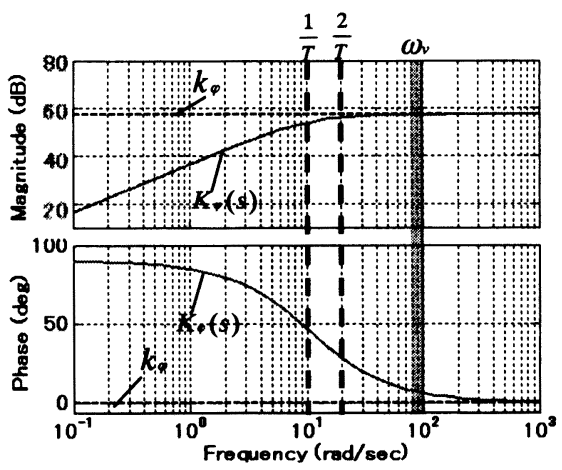

Fig. 4 Bode diagram of proposed suspension

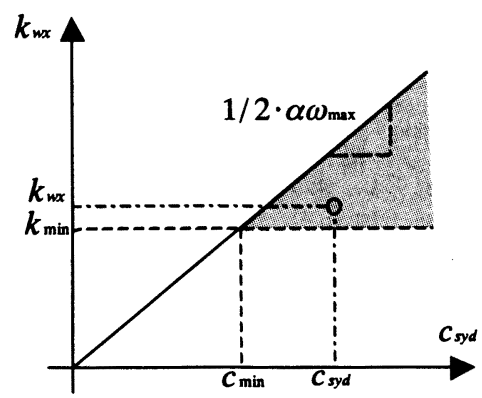

Fig. 5 Parameter plane for spring and damping coefficient 


\section{3. 車両モデルの走行安定性}

$3 \cdot 1$ 台車の權造 スケールモデル一車両モデル の数值解析によって, 前章の設計手法の有効性を検証 する. まず，製作した 1/10 スケール模型車両の外観 を図 6 に，台車部の詳細を図 7 に示す。台車構造は, ボルスタアンカを介して台車枠とボルスタを接続する インダイレクト・マウント方式四である. ボルスタと 車体間は芯皿結合によって,低摩擦の相対ヨーイング 運動を生成できる. ボルスタと台車枠間は片側上下 2 本の平行リンク構造によって, 台車枠ピッチングを発 生させることなく前後牽引力を伝達できる構造となつ ている. 上下枕ばねとしてボルスタ·台車枠間にコイ ルばねを導入している. コイルばねのみではボルス 夕·台車枠間の相対ローリング, 上下, 左右振動の減 衰が小さいため, 傾斜配置した油圧ダンパを取り付け ている. 台車枠・軸箱間は, 積層ゴム式軸箱支持機構 にならい, 防振ゴムで支持している. この剛性值はコ イルばねと比較して大きく設定してある.

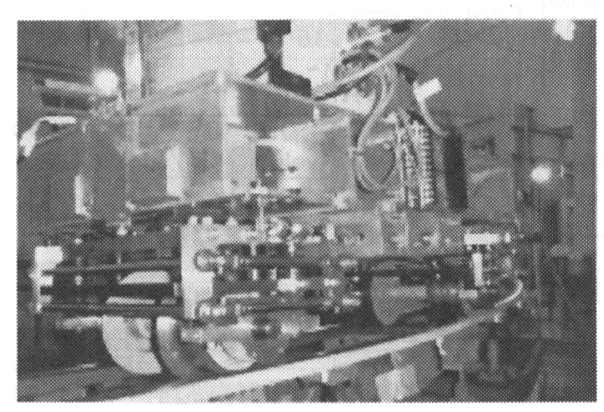

Fig. 6 Overview of $1 / 10$ scaled model vehicle

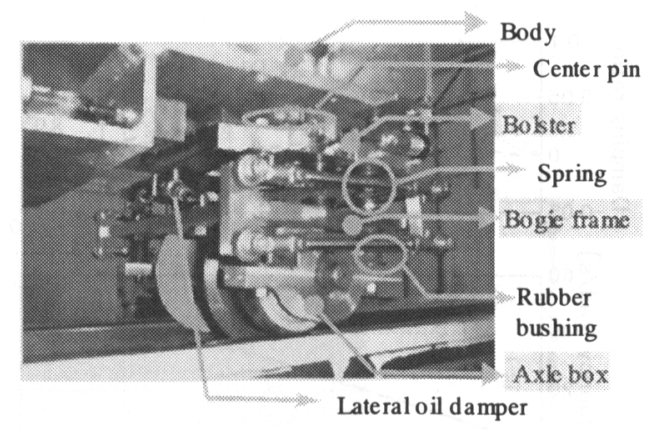

Fig. 7 Detail of proposed bogie mechanism
操舵性, 走行安定性に大きな影響をあたえる, ボ ルスタ・車体間支持装置は図 8 に示す三種類の方式 が可能である. 同図 (a) は支持装置として柔軟なば ねを用いた柔支持台車, 同図 (b)はボルスタ・車体間 をねじで固定し，剛性の大きな防振ゴムのみで輪軸 操舵力を受ける剛支持台車, 同図 (c) は提案する SYD で支持する提案台車である.

3.2 線形解析モデ 数值解析に用いる車両 モデルを図 9 に示す. 数值解析においては, 平行リン クと芯皿による拘束条件を考慮して, 車体左右・ロ一 ル・ヨー, ボルスタ・ヨー, 台車枠左右・ロール, 車輪 左右・ヨーによるモデリングである. これらのモデリ ングはマルチボディ・ダイナミクス解析ソフトウェア $\mathrm{A}^{\prime} \mathrm{GEM}{ }^{111}$ の運動方程式算出アルゴリズムを用いて算出 し，走行速度をパラメータとした固有值解析をおこな

う. 線形化モデルとして用いる車両諸元を表 1 に示す.

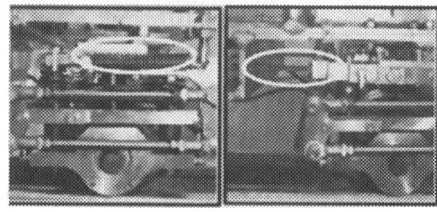

a) Spring b) Rigid

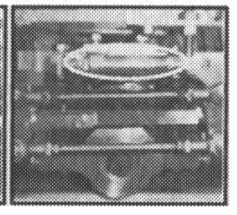

c) SYD
Fig. 8 Various suspensions between body and bolster
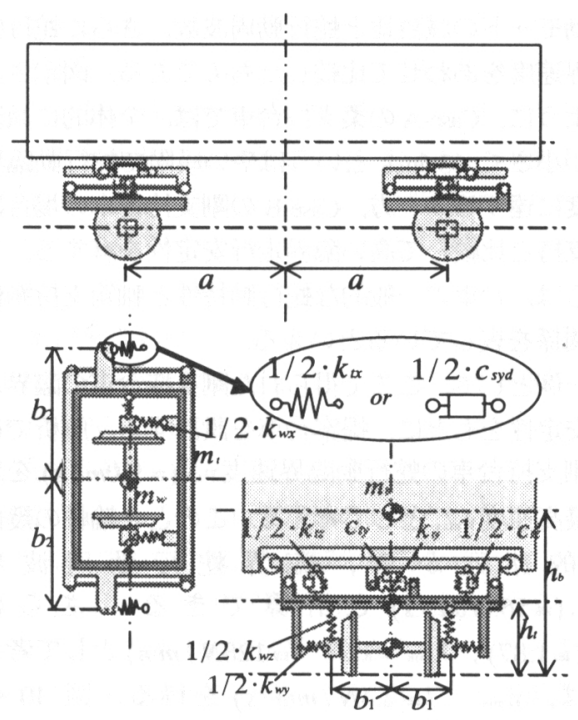

Fig 9 Vehicle model with two single-axle bogies 
Table 1 Parameter of the model vehicle

\begin{tabular}{|c|c|}
\hline $\begin{array}{l}\text { Body, bogie, link, axle mass } \\
\left(m_{b}, m_{t}, m_{l}, m_{w}\right)\end{array}$. & $46.5,4.8,0.2,4.5(\mathrm{~kg})$ \\
\hline Inertia radius of body $\left(i_{b x}, i_{b z}\right)$ & $85.0,200.0(\mathrm{~mm})$ \\
\hline Inertia radius of bogie $\left(i_{x}, i_{t_{z}}\right)$ & $50.0,80.0(\mathrm{~mm})$ \\
\hline Inertia radius of link $\left(i u_{x}\right)$ & $120.0(\mathrm{~mm})$ \\
\hline Inertia radius of wheel-axle $\left(i_{\mathrm{my}}, i_{\mathrm{wz}}\right)$ & $72.0,72.0(\mathrm{~mm})$ \\
\hline $\begin{array}{c}\text { Primary spring rigidity longitudinal, } \\
\text { lateral, vertical } \\
\left(k_{w x}, k_{w y}, k_{w z}\right)\end{array}$ & $\begin{array}{l}128.0,128.0,800.0 \\
\text { (N/mm, per axle box) }\end{array}$ \\
\hline $\begin{array}{l}\text { Secondary spring coefficient lateral, } \\
\text { vertical }\left(k_{y}, k_{z z}\right)\end{array}$ & $\begin{array}{l}72.0,4.0 .0 \\
(\mathrm{~N} / \mathrm{mm} \text {, per bogie) }\end{array}$ \\
\hline $\begin{array}{l}\text { Secondary damper coefficient lateral, } \\
\text { vertical }\left(c_{y y}, c_{t z}\right)\end{array}$ & $\begin{array}{l}0.26,0.15 \\
(\mathrm{~N} / \mathrm{mm} \cdot \mathrm{s} \text {, per bogie) }\end{array}$ \\
\hline Length between primary springs $\left(2 b_{1}\right)$ & $150.0(\mathrm{~mm})$ \\
\hline Length between secondary springs ( $\left.2 b_{2}^{\prime}\right)$ & $240.0(\mathrm{~mm})$ \\
\hline Length between bolster suspension $\left(2 b_{2}\right)$ & $280.0(\mathrm{~mm})$ \\
\hline Radius of wheel $(n)$ & $43.0(\mathrm{~mm})$ \\
\hline $\begin{array}{l}\text { Creep coefficient lateral, longitudinal } \\
\left(\kappa 11, \kappa_{22}\right)\end{array}$ & $\begin{array}{l}4.04 \cdot 10^{\wedge} 4 \\
3.62 \cdot 10^{\wedge} 4(\mathrm{~N})\end{array}$ \\
\hline Length of contact point $\left(2 b_{0}\right)$ & $150.0(\mathrm{~mm})$ \\
\hline Tread gradient $(\gamma)$ & $1 / 8$ \\
\hline Height of bogie $(\mathrm{m})$ & $96.0(\mathrm{~mm})$ \\
\hline Height of body $\left(h_{2}\right)$ & $204.0(\mathrm{~mm})$ \\
\hline Wheel base $(2 a)$ & $500.0(\mathrm{~mm})$ \\
\hline
\end{tabular}

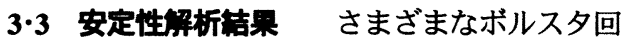
転支持機構について, 固有值解析による走行安定性 解析をおこなう. 支持機構のパラメー夕条件は表 2 にある 6 つの条件である. これら支持条件の一部は, 実験で比較する支持機構の数值に対応している.

図 10，11 はさまざまな支持条件で，走行速度を 変化させて, 一番はやい段階に不安定化する輪軸蛇 行動モードの減衰比と蛇行動周波数, さらに蛇行動 臨界速度をあわせて比較したものである. 図示され るように, Case-A の柔支持台車では, 全体的に減衰 比が小さく, $3.6 \mathrm{~m} / \mathrm{s}$ というはやい段階で蛇行動臨界 速度に達する. 一方, Case-B の岡支持台車の場合は, 柔支持と比較して高い臨界走行安定性を有する. こ れらは, 台車の一般的な蛇行動特性と軸箱支持剛性 の関係を表しているといえる.

一例として, ここで得られた剛支持台車の臨界走 行安定性をもとに，提案台車を設計する. 解析で得 た剛支持台車の蛇行動臨界速度 $v_{C R}(\approx 9.0 \mathrm{~m} / \mathrm{s})$ を想 定最高速度 $v_{\max }$ として考える. このとき輪軸の幾何 学的諸元から, 臨界蛇行動周波数 $\omega_{\max }(\approx 56.0 \mathrm{rad} / \mathrm{s})$ と計算できる。さらに $\alpha(\approx 1.87), k_{\min }=k_{\text {wx }} \quad(\approx 128 \mathrm{~N} / \mathrm{mm})$ として考え れば, $c_{\text {min }} \quad(\approx 2.4 \mathrm{~N} / \mathrm{mm} \cdot \mathrm{s})$ を得る. 図 10 の Case-C1 は，このとき得られた SYD 減衰係数を用い た場合の蛇行動減衰比の変化である. この提案台車 は走行速度の増大に伴い走行安定性が一時的に回復 し, 剛支持台車の性質に近づいているのがわかる.
結果的に，剛支持台車と同等の臨界走行速度を有し ているのが図示される.

図 11 はSYD の減衰係数を設計値より半減した場 合(Case-C2)と大きくした場合(Case-D1,Case-D2)の蛇 行動減衰比と周波数の推移を比較したものである. 図示されるように減衰係数を半減した場合, 全体的 な減衰比も小さく, 臨界走行速度も大きく低減して いるのがわかる. 一方, 減衰比を大きくした場合は, 全体的に減衰比が向上しており, 臨界走行速度もよ り剛支持台車の性質に近づいているのがわかる.

Table 2 Parameter of various suspensions

\begin{tabular}{|c|c|c|c|}
\hline Caption & Condition & Notation & Value \\
\hline Case-A & Spring & $k_{c x}$ & $8.0(\mathrm{~N} / \mathrm{mm})$ \\
\hline Case-B & Rigid & $k_{x x}$ & $\infty(\mathrm{N} / \mathrm{mm})$ \\
\hline Case-C1 & SYD & $c_{\text {syd }}$ & $2.4(\mathrm{~N} / \mathrm{mm} \cdot \mathrm{s})$ \\
\hline Case-C2 & SYD fail & $1 / 2 \cdot c_{\text {syd }}$ & $1.2(\mathrm{~N} / \mathrm{mm} \cdot \mathrm{s})$ \\
\hline Case-D1 & SYD $(\exp )$ & $c_{\text {exp }}$ & $6.4(\mathrm{~N} / \mathrm{mm} \cdot \mathrm{s})$ \\
\hline Case-D2 & SYD fail $(\exp )$ & $1 / 2 \cdot c_{\exp }$ & $3.2(\mathrm{~N} / \mathrm{mm} \cdot \mathrm{s})$ \\
\hline
\end{tabular}
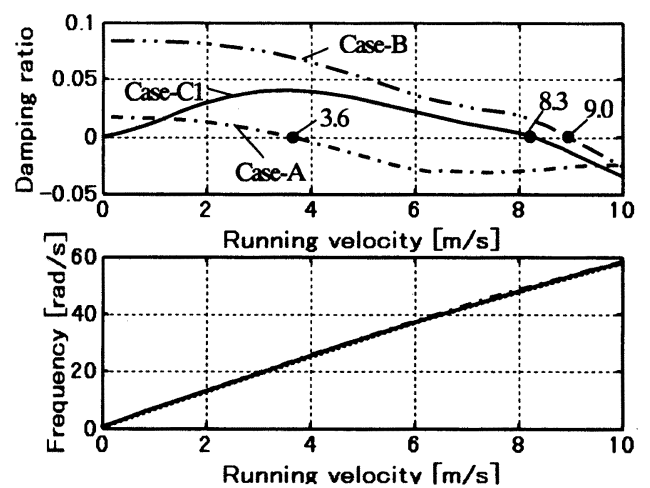

Fig. 10 Damping ratio and frequency for three types of bolster suspension
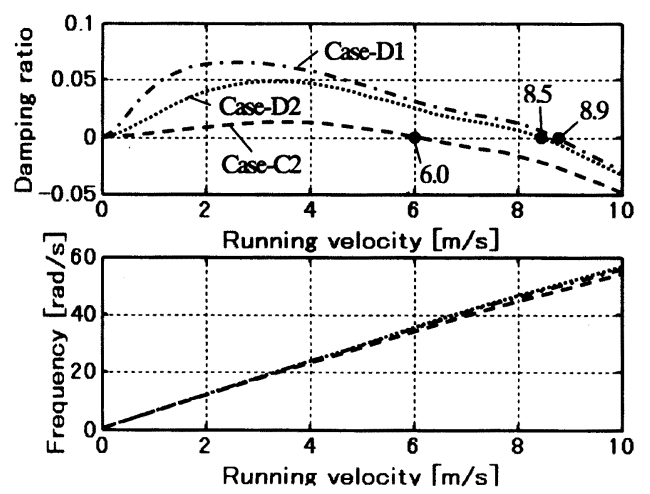

Fig. 11 Damping ratio and frequency for three types of damping coefficient of SYD 


\section{4. 車両モデルの走行安定性}

$4 \cdot 1$ 実験装置の計測システム 実験によって 数值計算で得られた結果を検証する. 走行安定性 解析に用いる軌道と牽引装置の全体図を図 12 に 示す. 模型車両は直線区間において, 並行して移動 可能な牽引駆動装置により任意の走行速度, 走行パ夕 ーンで率引走行される. 率引走行では車両を前後方向 に拘束することで最大 $2.5 \mathrm{~m} / \mathrm{s}$ までの直進走行安定性 試験をおこなうことができる.

模型車両の挙動を計測する車上計測システムの 概要を図 13 に示す。車両計測量は, 軸箱に取り 付けたレーザー変位計により, レールとの相対距 離を計測することで, 輪軸左右, アタック角を算 出する. また, 後軸にはロータリーエンコーダが 取り付けられており, 車両の走行速度, およびそ の積分值である走行距離を計測できる. これらセ ンサのデータは, 車上に設置したデータロガーに 記録される.

$4 \cdot 2$ 走行安定性解析軌道直線区間を用いた 走行安定性解析の実験結果について述べる. 実験に 際して, まず両輪軸を片側にフランジ接触する位置

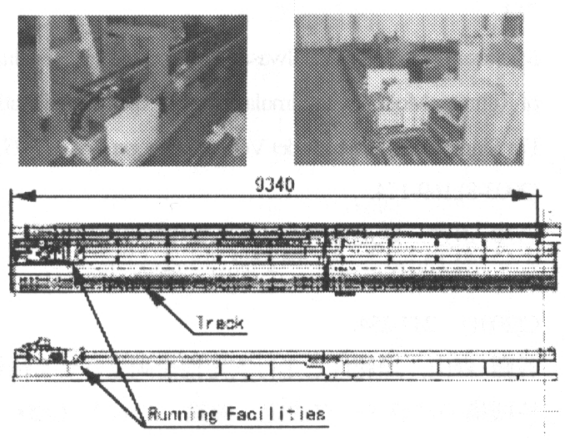

Fig. 12 Track and traction system

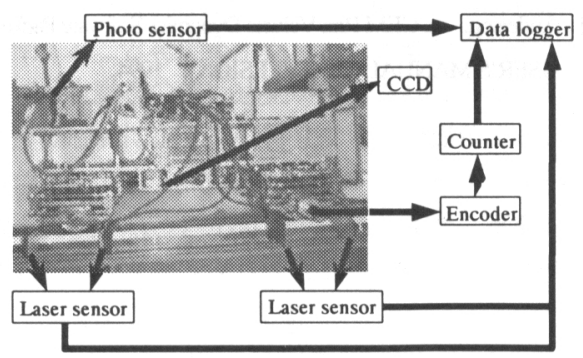

Fig. 13 On board measurement system (11.5mm)まで変位させつつ, 両輪軸のアタック角を零 とした状態を初期値とする。そして, 車両と率引装置 を前後方向に拘束し, 走行速度 $0.5 \mathrm{~m} / \mathrm{s} \sim 2.5 \mathrm{~m} / \mathrm{s}$ の範囲 で $0.5 \mathrm{~m} / \mathrm{s}$ 刻みで定速走行実験を繰り返す。このとき, 一例として図 14 にあるような時刻歴デー夕を取得で きる. デー夕から特徵量を算出するために, 走行速度 が安定し, かつ, レール継ぎ目やレールゆがみの小さ いと判断した区間 $(2.5 \mathrm{~m} \sim 4.0 \mathrm{~m})$ の, 前輪軸アタック角 変化に注目する. この区間における振幅の比から対数 減衰比

$$
\zeta=\frac{1}{2 \pi} \cdot \log \left(\frac{a_{1}}{a_{3}}\right)
$$

を算出して比較する. また，剛支持台車など減衰の大 きい台車では, 定常状態における振動が発生しないた め, 振動振幅が $0.3[\mathrm{deg}$ 以上の過渡的な部分で振幅比 を計算することとした. 各走行速度に対して三回ずつ 試行を繰り返し，データを収集する.

$4 \cdot 3$ 実検拮果と考察 図 15 は, 各試行で得ら れた減衰比について, 同一速度で三回繰り返して得ら れる減衰比の平均值を折れ線でつなぎ, 減衰比の速度 依存性を表した図である. ボルスタの支持条件は 4 種 類であり, 支持機構の岡性値は数值解析で用いた表 2 に対応している.

図示されるように, 柔支持台車(Case-A)では, 全体 的に減衰比が小さく, 速度增大にしたがって徐々に減 衰比が低下する. しかし, 前後支持岡性の大きい岡支 持台車(Case-B)は, より高い減衰比を有しつつ, 徐々 に走行速度が低下している.これは一般的な輪軸蛇行 動特性と前後支持剛性の関係を表しているといえる.

一方, 提案台車(Case-D1)は高速になるほど減衰比が 高くなり, $0.5 \mathrm{~m} / \mathrm{s}$ 時には従来台車と同程度であった減 衰比が, $25 \mathrm{~m} / \mathrm{s}$ 時には剛支持台車に近い隇衰比となつ ている.

提案台車において, ボルスタ左右に取り付けられ た片側のダンパを取り外し,フェイル状態を模擬した 場合が図中の Case-D2である.この場合, ボルス夕回 転抵抗が半減するため, 減衰比の立ち上がりが小さく なっているものの, 走行安定性の回復という点では, フェイルしていない場合と同様の傾向を示す．この支 持条件では, フェイル状態であっても式(10)の条件を 満たすため, 前章の数值解析結果から, さらなる走行 速度増大で剛支持台車の傾向に近づくことが予想され る. このようにフエイル状態で条件を満たすように設 計することで, 安全性の高い実用的な台車設計をおこ なうことができる. 

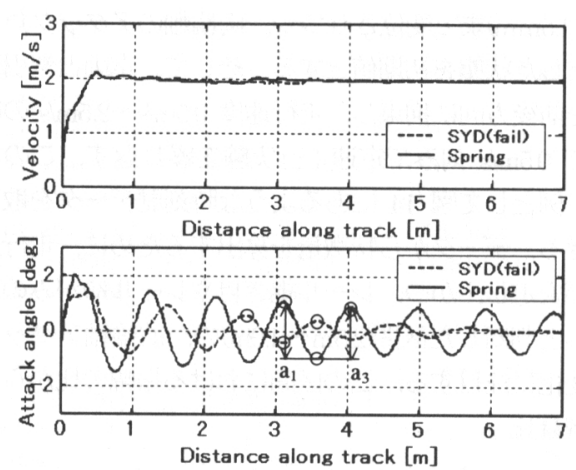

Fig. 14 An example of data for 1st axle attack angle

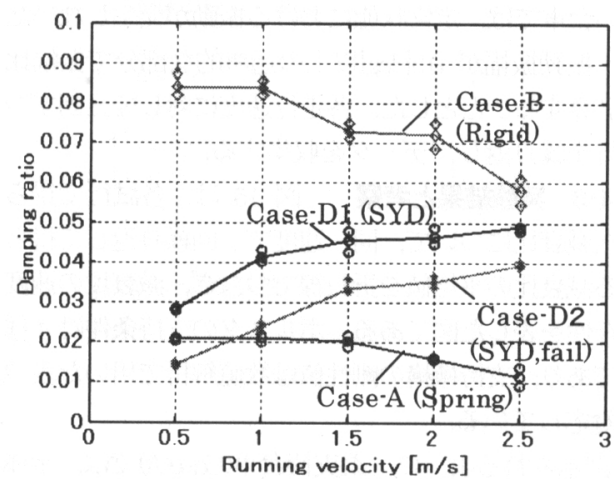

Fig. 15 Comparison of damping ratio for various suspensions

\section{5. 結}

本報告では，提案する鉄道車両一軸操舵台車につ いて, 輪軸蛇行動周波数に基づいて走行安定性を設 計する手法を述べた. また, 製作した模型実験装置 の数值解析と実験により, 走行安定性に関する提案 台車の有効性を検証した. 得られた知見を以下に示 す.

（1）輪軸単体の伝達関数モデルの特徵から, 輪 軸の臨界蛇行動周波数 $\omega_{\text {max }}$ と軸箱前後支持剛性 $k_{w x}$ をもとに, SYD減衰係数 $c_{\text {syd }}$ を決定するパラメー夕 設計条件を提案した.

（2）提案するパラメー夕設計手法は輪軸単体モ デルに基づくものであるが，一車両モデルにおいて も, 走行安定性を適切に設計できることを固有値解 析により示した.

（3） スケールモデル実験装置により，剛支持台 車，柔支持台車が一般的な蛇行動特性と前後支持剛 性の関係を満たすことと同時に, 提案台車が走行速
度の増大により剛支持台車の蛇行動安定性に収束す る傾向を確認した。

今後の課題は, 実車を対象とした数值解析と実験 である. また, 提案操舵台車の極低速時における蛇 行動减衰特性の向上を視野に入れた, アクティブ制 御への拡張についても，理論解析と実験による検討 を進めていく予定である.

\section{文献}

[1] 高性能·低コスト 1 軸台車の開発，日本鉄道技術協会， 平成 11 年度報告書, (2000-9).

[2] 須田, 一軸台車を持つ鉄道車両の曲線旋回性能, 生産研究, 50-5, (1998-3).

[3] 須田・ほか 5 名, 試作一軸台車の実車走行試験で蛇行 動特性に関する検討，鉄道技術連合シンポジウム， (2000-12), 277-280.

[4] 宮本·加藤·須田，一軸台車を装備した鉄道車両の運 動, 第 7 回交通物流部門大会, 98-37, (1998-12), 309 312.

[5] 須田·宮本, 車両の運動力学入門, 鉄道車両と技術, 3-6, (1997), 23-24.

[6]須田·柴野, 鉄道車両用一軸台車の走行性能改善, 日 本機械学会機械力学·計測制御部門講演会, (2001-9), 713.

[7] Michitsuji, Y., Suda, Y., Iwasa, T., Komine, H., Evaluation of Running Motion with Simulation and Experimental Platform For Single-Axde Scale Model Vehicle. Proc on STECH'03, (2003-8),169-174.

[8] 谷藤·道辻, 鉄道車両の走行安定性判別のための一手 法と操舵性台車設計への応用, 機論, 66-641, C(2001), 247-254.

[9] 谷藤·森山, 操舵性と走行安定性を両立させる輪軸支 持機構のパラメー夕決定, 機論, 67-662, C(2001), 168-174.

[10] 日本機械学会編, 鉄道車両のダイナミクス, (1994), 12, 電気車研究会.

[11] Anderson, A'GEM Rail Vehicle Dynamics Software Package USER'S MANUAL(DOS VERSION), 1994. 